\title{
Model Penjernih Air Hujan Untuk Air Bersih
}

\section{Rain Water Purified Model For Clean Water}

\author{
RD Lufira ${ }^{1}$, L Zuhriyah ${ }^{2}$, SD Muktiningsih ${ }^{3}$, AP Rahayu ${ }^{4}$, DA Fauzi ${ }^{5 *}$ ) \\ 1,5Jurusan Teknik Pengairan, Fakultas Teknik, Universitas Brawijaya, Malang 65145, Indonesia \\ ${ }^{2}$ Jurusan Kesehatan Masyarakat, Fakultas Kedokteran, Universitas Brawijaya, Malang 65145, Indonesia \\ ${ }^{3}$ Jurusan Teknik Lingkungan, Fakultas Teknologi Pertanian, Universitas Brawijaya, Malang 65145, Indonesia \\ ${ }^{4}$ Jurusan Budidaya Pertanian, Fakultas Pertanian, Universitas Brawijaya, Malang 65145, Indonesia
}

\section{Article info:}

Kata kunci:

air bersih; kualitas air; penjernih air

Keywords:

clean water; water quality; water purifier

\section{Article history:}

Received: 24-01-2021

Accepted: 13-06-2021

${ }^{*}$ Koresponden email: rahmahdara@ub.ac.id

\begin{abstract}
Abstrak
Menabung air hujan adalah salah satu upaya untuk mengendalikan kekurangan air dimusim kemarau. Sistem penjernih air hujan menjadi air bersih ini adalah rangkaian kegiatan gerakan menabung air hujan dan menggunakannya kembali untuk konservasi air tanah serta kebutuhan sehari-hari. Desa Arjosari mengalami kekurangan air bersih pada saat musim kemarau, maka dari itu peneliti membuat sistem penjernih air ini dengan memanfaatkan air hujan. Metode yang digunakan adalah tandon air kemudian pipa penjernih yang terdiri dari Zeolit, kerikil, Arang, ijuk dan spoons. Hasil analisa yang telah dilakukan dilaboratorium menggunakan parameter logam metode AAS (atomic absorbance spectrofotometri), parameter anion (spectrofotometer uv vis), dan parameter fisik (water quality checker dan tss meter). Didapatkan rata-rata nilai untuk pH 6,71, TSS 0, TDS 40,3, CaCO3 0, kandungan besi 0,032, Mangan 0,113. Dilihat dari hasil pengujian yang telah dilakukan, hasil yang diperoleh memenuhi persyaratan Peraturan Menteri Kesehatan Republik Indonesia No. 2. 492/Menks/PER/IV/2010. Air tersebut dapat dipergunakan sebagai syarat untuk menggunakan air bersih.
\end{abstract}

\section{Abstract}

Saving rainwater is one of the efforts to control water shortages in the dry season. This rainwater purification system clean water is a series of activities to save rainwater and reuse it for groundwater conservation and daily needs. Arjosari Village experiences a shortage of clean water during the dry season, therefore the researchers made this water purification system by utilizing rainwater. The method used is a water reservoir and then a purifying pipe consisting of Zeolite, gravel, charcoal, palm fiber, and spoons. The analysis results have been carried out in the laboratory using the metal parameters of the AAS method (atomic absorbance spectrophotometry), anion parameters (UV VIS spectrophotometer), and physical parameters (water quality checker and TSS meter). The average values were obtained for $\mathrm{pH} 6.71$, TSS 0, TDS 40.3, CaCO3 0 , iron content 0.032 , Manganese 0.113 . From the results of the tests that are conducted, obtained results that meet the standards with the wants consistent with the Regulation of the Minister of Health of the Republic of Indonesia No. 492/MENKES/PER/IV/2010. So the water to be used meets the wants for the utilization of unpolluted water.

Kutipan: Lufira, R.D, Zuhriyah, L., Muktiningsih, S.D., Rahayu, A.P., Fauzi, D.A, Model Penjernih Air Hujan Untuk Air Bersih, Jurnal Teknik Pengairan. https://doi.org/10.21776/ub.pengairan.2021.012.01.06 


\section{Pendahuluan}

Menurut data Puskesmas Kalipare, persentase desa di Kecamatan Kalipare yang memiliki akses air minum berkualitas antara 62\% hingga 78\%, sedangkan tingkat ketersediaan air di Desa Arjosari hanya 67,7\%. 5 Dari wawancara dengan Kepala Desa Arjosari didapatkan data bahwa saat ini di desa Arjosari sudah terdapat tiga titik sumber air dalam $(100-120 \mathrm{~m})$ yang digunakan untuk penduduk setempat. Namun jumlah air tersebut belum mencukupi kebutuhan warga desa. Selama musim kemarau biasanya BPBD mensuplai air bersih sebanyak 3 tanki ke desa ini setiap 2-3 hari hari sekali. Masih rendahnya akses air bersih dapat menjadi salah satu alasan beberapa permasalahan Kesehatan seperti belum tercapainya Open Defecation Free (ODF) di desa Arjosari. Open defecation yaitu merupakan tindakan membuang kotoran atau tinja secara sembarangan pada area terbuka kemudian membiarkannya menyebar sehingga mengkontaminasi lingkungan, tanah, air, dan udara. Tidak hanya itu, rendahnya akses air bersih bisa meningkatkan angka penyakit infeksi. Dari data kepemilikan jamban di Kecamatan Kalipare tahun 2017, saat ini diperkirakan terdapat 456 rumah yang belum memiliki jamban sehat di desa tersebut. Data Puskesmas 2017 juga menyebutkan bahwa diare merupakan penyakit terbanyak yang berkunjung di Puskesmas Kalipare pada periode Januari Desember 2017.

Mengingat pentingnya manfaat dan dampak akses air bersih, maka akses air bersih merupakan salah satu target dari Sustainable Developmental Goal (SDG's). Upaya yang telah dilakukan untuk desa Arjosari saat ini adalah dengan membuat sumur dengan kedalaman 100-120 m untuk kemudian airnya dialirkan ke lokasi yang terdekat. Namun upaya ini belum bisa mencukupi kebutuhan air warga. Dan upaya yang ada sekarang ini, desa Arjosari belum memanfaatkan air hujan yang turun selama lebih kurang 5-6 bulan. Untuk itu perlu dilakukan upaya memanfaatkan air hujan secara optimal dengan melibatkan masyarakat secara maksimal. Air hujan yang turun melalui atap rumahrumah sebisa mungkin harus dimanfaatkan dengan baik, agar air tersebut tidak hanya melimpas di permukaan saja. Namun air hujan tersebut masih belum memenuhi tingkat kejernihan yang layak untuk air minum, masalah bakteri yang terdapat di kualitas air dan juga air hujan dapat terkontaminasi oleh sampah dan debu di daerah tangkapan (catchment area) atap rumah atau gedung. Masalah serangga dapat berkembang biak dengan bertelur di air juga menjadi perhatian jika menggunakan air hujan yang tertampung. Berbagai upaya dapat dilakukan untuk tetap bisa menikmati air bersih, diantaranya merebus air hingga mendidih, melakukan metode penyulingan, ataupun dengan teknologi yang ramah lingkungan. Salah satu metode yang dipakai adalah Rain Harvesting atau memanen air hujan. Kegiatan pemanenan air hujan merupakan suatu aktifitas dimana air yang turun ke permukaan bumi dalam suatu waktu yang kemudian ditampung pada wadah sehingga air hujan tidak menjadi run off atau air limpasan (mengalir ke pembuangan). Air hujan yang turun melalui atap rumah tidak dapat digunakan seluruhnya karena telah mengalami proses evaporasi pada atap dan juga karena koefisien limpasan pada atap bangunan tersebut. Pada artikel ini difokuskan pada penjernihan air hujan melalui pipa filter yang teradapat beberapa komponen filterisasi antara lain zeolite, pasir, kerikil, ijuk. Dari beberapa media filterisasi meimiliki kemampuan masing masing untuk menurunkan beberapa parameter air sehingga dapat memenuhi syarat dari ketentuan yang berlaku. Zeolit memiliki peran adsorpsi antara adsorben (penyerap) dan adsorbat (belitan) serta peran menyaring padatan akibat kevakuman di dalam zeolit.Prinsip lain zeolit adalah menjaga viskositas sebagai penukar ion. Kerikil dan pasir berperan dalam menyerap padatan atau kotoran yang masih lolos dari media filter sebelumnya (Untari \& Kusnadi, 2015). ijuk berperan sebagai penyaring kotoran yang masih lolos dari media pasir. Pipa filter ini nantinya yang diharapkan mampu meningkatkan kadar kualitas dari air hujan tersebut sehingga air layak untuk diminum ataupun digunakan untuk keperluan rumah tangga.

Media air yang digunakan dalam menentukan baku mutu sanitasi lingkungan meliputi parameter fisik, biologi dan kimia, parameter tersebut dapat berupa wajib atau lainnya. Parameter wajib adalah parameter yang harus dipantau secara diatur dalam peraturan perundang-undangan, parameter lain perlu diperiksa. Untuk mengetahui kondisi geografis dan hidrologi menunjukkan bahwa parameter tersebut mungkin terkontaminasi relatif terhadap parameter lain (Menteri Kesehatan Republik Indonesia, 2017). Untuk parameter wajib terdiri dari:

A. parameter fisik (Warna, Suhu, Rasa, Bau, kekeruhan, dan zat padat terlaurt (TDS))

B. Parameter biologi antara lain E. Coli dan total coliform 
Lufira, Zuhriyah, Muktiningsih, Rahayu, Fauzi : Model Penjernih Air Hujan Untuk Air Bersih

C. Parameter kimiawi antara lain Nitrit sebagai $\mathrm{NO}_{2}^{-}$, Mangan, $\mathrm{CaCO}_{3}, \mathrm{pH}$, Flourida, Nitrat sebagai $\mathrm{N}_{3}^{-}$, sianida, deterjen, pestisida total.

Pada penelitian ini untuk parameter biologi tidak dimasukkan karena ada keterbatasan waktu dan dana, dan memang dititik beratkan pada perbandingan parameter fisik dan kimiawi air hujan sebelum dan sesudah disaring sehingga hasil dari pemanenan air hujan tersebut dapat berfungsi dengan tepat dan mampu memenuhi standart baku mutu air.

\section{Bahan dan Metode}

\subsection{Bahan}

Perencanaan sistem penjernih air yang merupakan bagian dari kegiatan menabung air hujan ini merupakan sistem yang dibuat melalui beberapa langkah. Untuk membangun sistem peneliti merujuk kepada peraturan yang berlaku tentang Sumur resapan dan pernjernih air yang dilakukan oleh Erma Handasari dkk tahun 2017. Komponen utama dari penjernih air ini antara lain Tandon air dengan total tampungan 150 liter digunakan untuk menampung air dari talang, talang rumah tipe PVC yang digunakan untuk mengalirkan air dari atap rumah menuju ke tandon yang pertama, pipa PVC berukuran 3" yang digunakan untuk mengalirkan air serta sebagai tempat melakukan filterisasi air, dan media filterisasi. Media filterisasi ini terdiri dari zeoilit, kerikil, pasir, ijuk, spon dan arang. Komponen pendukungnya terdiri dari besi penyangga yang digunakan untuk menyangga tandon pertama, semen dan batu bata digunakan untuk menguatkan konstruksi dari besi penyangga serta membuat pondasi telapak, kran air digunakan untuk mengeluarkan air dari tandon yang kedua, dan buis beton digunakan untuk membuat sumur resapan air limpasan dari tandon yang pertama.

\subsection{Desain dan Mekanisme Sistem Penjernihan Air}

Pengambilan air pemanenan air hujan ditunjukkan pada gambar dibawah ini. Cara kerja dari penjernih air yaitu: air dari talang atap masuk ke pipa kemudian ditampung pada tandon yang pertama. Air dari tandon tersebut kemudian dialirkan menuju tandon yang kedua, dimana akan dilakukan penjernihan air melalui pipa filter yang sudah dipasang dengan komponen filterisasi didalamnya. Komponen yang terdapat pada pipa filter antara lain zeolite, krikil, pasir, ijuk, spon, dan arang. Ketika air pada tandon pertama dalam kondisi penuh, dapat dialirkan kedalam sumur resapan, yang mana pada sumur resapan nanti dapat berfungsi sebagai air tanah ditunjukan pada Gambar 1 .

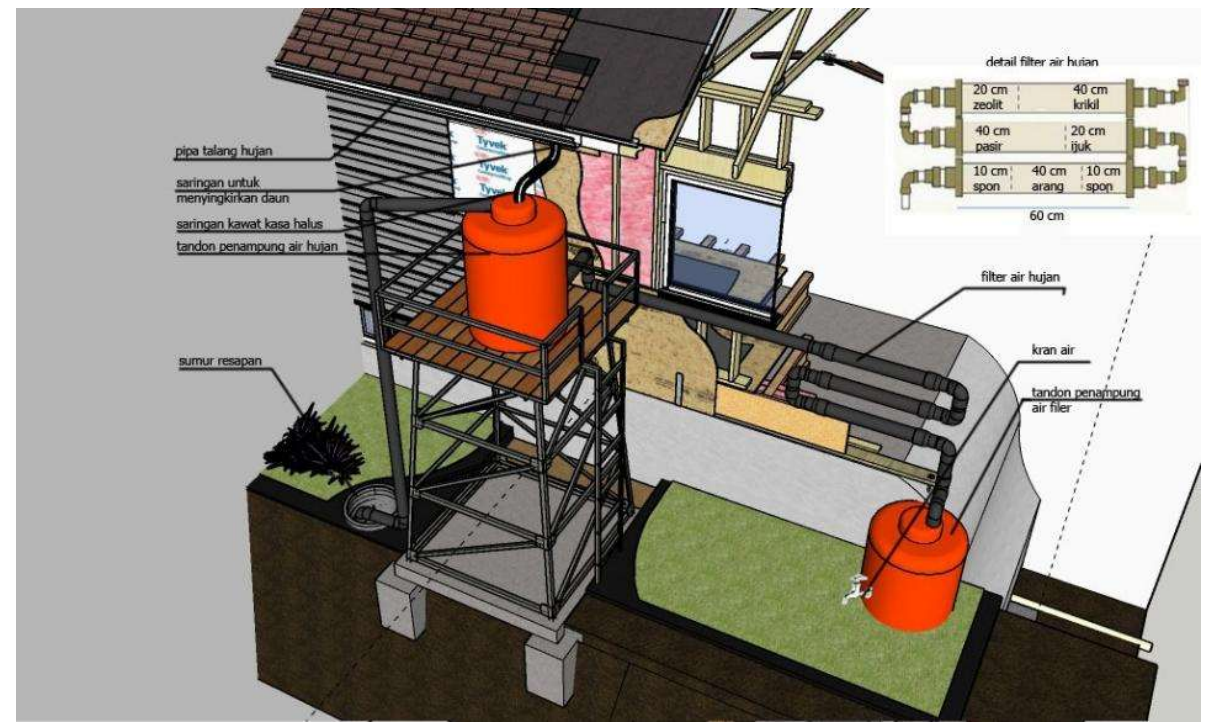

Gambar 1. Sistem penjernihan air

Gambar 2 adalah detail sistem pipa penjernih air sebelum memasuki tandon bawah yang berfungsi sebagai tandon akhir yang dapat dipergunakan langsung untuk keperluan sehari-hari. Isian dan jarak 
yang dipergunakan ini merujuk salah satu tulisan ilmiah di prosiding seminar nasional (Handarsari, dkk. 2017) dengan menyesuaikan dengan kapasitas dan perencanaan kami dilapangan.

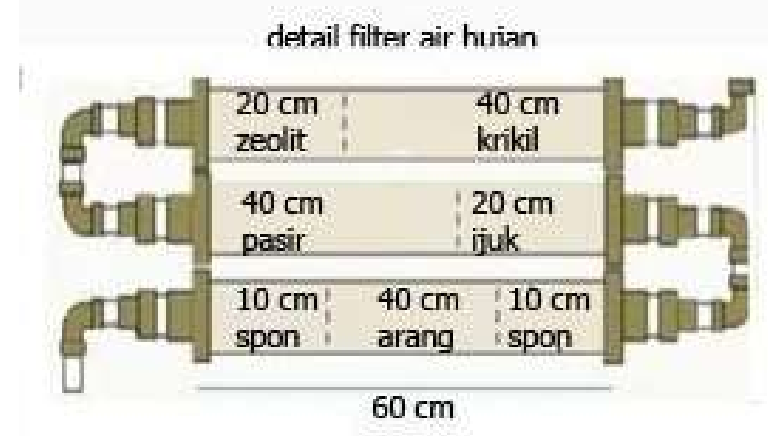

Gambar 2. Filter penjernih air hujan

\subsection{Teknik Pengambilan Sampel Air}

Pengujian sampel dilakukan di Laboratorium Air Tanah, Jurusan Teknik Pengairan Universitas Brawijaya. Air sampel diambil sebanyak 6 botol dan diberi penamaan untuk membedakan sampel sebelum dilakukan filterisasi dan setelah dilakukan filterisasi. Setiap botol yang diambil sebanyak 1.5 liter. Pengambilan air sampel dilakukan pada hari Jumat, 6 November 2020. Untuk botol A adalah air yang diambil dari tandon atas sebelum ada pipa filter, dan botol B adalah air yang diambil di tandon bawah setelah ada pipa filter penyaringan. Cara pengambilan sample air ditunjukan pada Gambar 3.

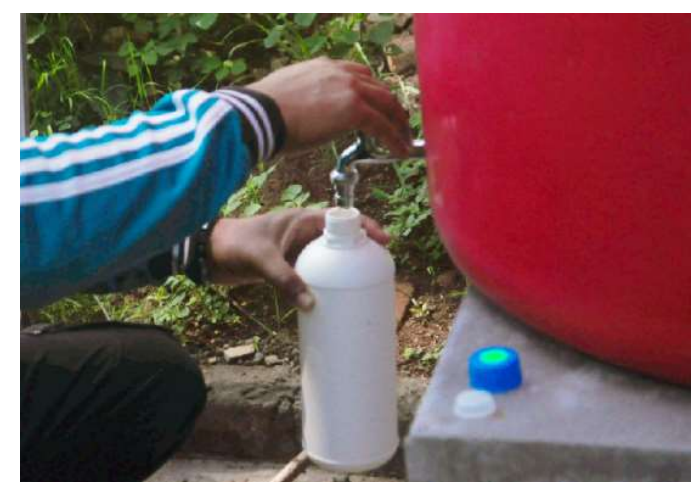

Gambar 3. Pengambilan sampel air Botol B

Setelah dilakukan penjernihan air, untuk menguji kualitas air tersebut dilakukan tes sampel yang dilakukan di laboratorium. Banyak parameter yang diuji untuk menentukan kualitas air. Dalam menguji sampel dilakukan beberapa metode teoritis untuk mengetahui nilai dari sebuah parameter. Pengujian kali ini menggunakan beberapa metode sesuai parameter masing-masing.

\subsection{Metode Pengujian}

\subsubsection{Parameter logam}

Metode AAS (Atomic Absorbance Spectrophotometer) adalah alat untuk menganalisis unsur logam dan metaloid, dan pengukurannya didasarkan pada penyerapan cahaya dengan panjang gelombang tertentu oleh atom logam dalam keadaan bebas (Skoog, 2000). Spektrofotometri serapan atom (AAS) melibatkan penyerapan cahaya oleh atom netral dari unsur logam yang masih dalam keadaan dasar. Prinsip AAS pada dasarnya sama dengan penyerapan cahaya oleh molekul kompleks atau ion dalam larutan (Gupta dan Roy, 2007).

Prinsip kerja spektrofotometri serapan atom ini adalah berdasarkan atas penguapan larutan sampel, kemudian logam yang terkandung di dalamnya diubah menjadi atom bebas. Atom tersebut mengabsorpsi radiasi dari sumber cahaya yang dipancarkan dari lampu katoda yang mengandung 
Lufira, Zuhriyah, Muktiningsih, Rahayu, Fauzi : Model Penjernih Air Hujan Untuk Air Bersih

unsur yang akan ditentukan. Banyaknya penyerapan radiasi kemudian diukur pada panjang gelombang tertentu menurut jenis logamnya. Peralatan dari metode AAS antara lain sumber cahaya, monokromator dapat digunakan untuk memisahkan radiasi yang tidak dibutuhkan dari spektrum radiasi lain, detector digunakan untuk mengubah energi cahaya menjadi energi listrik, sel absoprsi, rekorder, system pencatat. Dalam analisa secara spektrofotometri ada beberapa metode antara lain (Untari \& Kusnadi, 2015):

1. Metode kalibrasi kurva. Dalam metode kurva kalibrasi ini, serangkaian larutan standar dari berbagai konsentrasi disiapkan, dan absorbansi larutan diukur dengan spektrometri serapan atom.

2. Metode standar tunggal. Cara ini sangat praktis karena hanya menggunakan larutan standar yang diketahui konsentrasinya.

3. Penambahan standar. Metode ini banyak digunakan karena dapat meminimalkan kesalahan yang disebabkan oleh perbedaan antara sampel dan kondisi lingkungan standar (matriks). (Syahputra, 2004)

Adapun pengolahan data penetapan parameter logam untuk samepl air adalah:

Kadar Logam $=$ Pembacaan SSA $(\mathrm{mg} / \mathrm{L}) \times$ Volume akhir $(\mathrm{mL})$

$100 \mathrm{~mL}$

Kemudian pada metode spektrofotometri serapan atom (SSA), Keuntungannya adalah sensitivitasnya lebih tinggi, sistemnya relatif mudah dan suhu yang dibutuhkan dapat dipilih, tetapi kelemahan metode ini adalah digunakan hanya untuk larutan konsentrasi rendah, membutuhkan jumlah larutan yang relatif besar (10-15 mL) dan membutuhkan alat penyemprot untuk terbentuk. Aerosol konsentrasi rendah (Wardani, 2017).

\subsubsection{Parameter Anion}

Spectrofotometric UV-Vis Ini adalah metode analisis untuk penentuan elemen anionik dalam sampel air. Tahapan spektrofotometri UV-Vis, pertama siapkan larutan blanko, larutan blanko yang digunakan adalah blanko pelarut yang digunakan untuk melarutkan sampel yaitu hijau muda. Pada percobaan tersebut digunakan larutan blanko sebagai kontrol spektrofotometer berupa sampel air. Pada spektrofotometri sinar tampak (UV-Vis), keuntungan yang didapatkan adalah panjang gelombang cahaya putih dapat dipilih. Metode itu sangat sederhana dan dapat menganalisa larutan dengan konsentrasi yang sangat kecil. Kekurangan dari penggunaan metode ini adalah absorpsi sangat dipengaruhi oleh nilai $\mathrm{pH}$, suhu dan zat pengganggu dari larutan. Ada dampak dan kebersihan kuvet hanya dapat digunakan di daerah ultraviolet dengan panjang gelombang lebih dari $185 \mathrm{~nm}$ (Wardani, 2017).

Alat-alat instrumentasi Spektrofotometer UV-Vis terdiri dari:

1. Sistem Optik

Untuk konfigurasi dasar setiap spektrofotometer Uv-Vis adalah urutan peralatan optic yang harus terurut sebagai berikut:

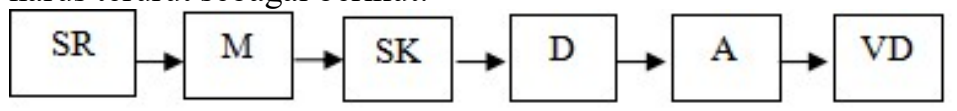

Keterangan:

SR $\quad=$ Sumber Radiasi

$\mathrm{M} \quad=$ Monokromator

SK $\quad=$ Sampel Kompartemen

$\mathrm{D} \quad=$ Detektor

A $\quad=$ Amplifier atau penguat

VD $=$ Visual display atau meter

2. Sumber radiasi

Dari beberapa sumber radiasi yang digunakan dalam spektrofotometer ultraviolet tampak adalah lampu deuterium, lampu tungsten, dan lampu merkuri. Sumber radiasi deuterium dapat digunakan pada rentang panjang gelombang $190 \mathrm{~nm}$ hingga $380 \mathrm{~nm}$ (wilayah ultraviolet dekat), karena pada rentang panjang gelombang ini, sumber radiasi deuterium 
menyediakan dua garis spektral, yang dapat digunakan untuk memeriksa spektrofotometer UV-tampak. (Dachriyanus, 2004).

3. Monokromator

Monokromator adalah suatu part dalam proses Spektrofotometer UV-Vis untuk mendapatkan radiasi monokromatik dari sumber radiasi polikromatik. Monokromator biasanya terdiri dari susunan sebagai berikut: slot masuk-filter-prisma-grating-keluar.

4. Sel atau kuvet

Kuvet atau sel adalah tempat sampel yang akan dianalisis, diamana peninjauan dari pemakaian kuvet ada dua macam yaitu, kuvet permanen yang terbuat dari bahan gelas hasil leburan silika dan kuvet disposable yang pemakaiannya untuk satu kali terbuat dari bahan teflon atau plastik.

5. Detektor

Kualitas detektor sangat menentukan kualitas spektrofotometer Uv-Vis. Berfungsi sebagai pengubah sinyal radiasi menjadi sinyal elektronik.

\subsubsection{Parameter fisik}

Water Quality Checker ini sebagai alat untuk mengukur kualitas air, mengukur oksidasi dalam air, mengukur kadar oksigen dalam air dan lain sebagainya. Dari pemeriksa kualitas air ini, kita bisa mengetahui apakah air tersebut tercemar limbah. Untuk standar parameter fisik sesuai Peraturan Menteri Kesehatan Republik Indonesia No. 492/MENKES/PER/IV/2010 yaitu tidak memiliki bau, tidak memiliki rasa, batas nilai Total Zat padat terlarut (TDS) yaitu $500 \mathrm{mg} / 1$, nilai kekeruhan yaitu $5 \mathrm{NTU}$, dan suhu berkisar antara $3^{\circ} \mathrm{C}$, dapat dilihat pada Tabel 1 .

Tabel 1 Parameter Fisik dalam Standar Baku Mutu Kesehatan Lingkungan Untuk Media Air untuk Keperluan Higiene Sanitasi

\begin{tabular}{|l|l|l|l|}
\hline No & Parameter wajib & Unit & $\begin{array}{l}\text { Standar baku mutu } \\
\text { (Kadar maksimum) }\end{array}$ \\
\hline 1 & Kekeruhan & NTU & 25 \\
\hline 2 & Warna & TCU & 50 \\
\hline 3 & $\begin{array}{l}\text { Zat padat terlarut (Total } \\
\text { Dissolved Solid) }\end{array}$ & $\mathrm{Mg} / 1$ & 1,000 \\
\hline 4 & Suhu & ${ }^{\circ} \mathrm{C}$ & Suhu udara \pm \\
\hline 5 & Rasa & - & Tidak terasa \\
\hline 6 & Bau & - & Tidak berbau \\
\hline
\end{tabular}

\section{Hasil dan Pembahasan}

Hasil analisa yang dilakukan di Laboratorium Air tanah Jurusan Teknik Pengairan ini didapatkan hasil dari sampel yang diambil adalah sebagai berikut ;

1. $\mathrm{pH}$

Parameter $\mathrm{pH}$ ini merupakan parameter yang menunjukkan konsentrasi aktif ion hidrogen dalam air dan sebagai ukuran kualitas air. Dalam air biasa yang tidak asam maupun basa, $\mathrm{pH}$-nya $=7$. Tingkat $\mathrm{pH}$ yang baik tetap dapat membuat kehidupan biologis di air berfungsi normal (Sugiharto, 1987). Dari sudut pandang $\mathrm{pH}$, seharusnya tidak bersifat asam atau non-basa untuk mencegah pencucian logam berat dan korosi pada jaringan distribusi air.

Dari hasil Analisa sampel A1 memiliki nilai pH 6.88, sampel A2 memiliki nilai pH 6,79, dan untuk sampel A3 memiliki nilai pH 6,73. Sedangkan untuk sampel B1, B2, dan B3 merupakan sampel yang sudah mengalami filterisasi melalui pipa filter. Sampel B1 memliki nilai $\mathrm{pH}$ 6,74, sampel B2 memiliki nilai $\mathrm{pH}$ 6,72, dan untuk sampel B3 memiliki nilai $\mathrm{pH}$ 6,68. Dari kedua sampel A dan B dapat disimpulkan masih berada diantara nilai 6,5-8,5, artinya nilai $\mathrm{pH}$ dari kedua sampel memenuhi syarat untuk kualitas air minum sesuai standar kualitas air.

2. TDS

Total Dissolved Solids (TDS) merupakan zat terlarut (berdiameter 10-6 mm) dan koloid (berdiameter 10-6 mm sampai dengan 10-3 mm) dalam bentuk senyawa dan zat lain yang tidak digunakan pada kertas saring dengan diameter 0,45 mikron. TDS dapat disebabkan oleh bahan 
Lufira, Zuhriyah, Muktiningsih, Rahayu, Fauzi : Model Penjernih Air Hujan Untuk Air Bersih

anorganik berupa ion umum terdapat dalam air. Nilai TDS air juga sangat dipengaruhi oleh pelapukan batuan, limpasan tanah, dan pengaruh manusia (berupa limbah rumah tangga dan industri).

Dari hasil sampel yang sudah dianalisa diketahui nilai dari TDS sampel A1 sebesar $39 \mathrm{mg} / \mathrm{L}$, sampel A2 yaitu $34 \mathrm{mg} / \mathrm{L}$, dan sampel A3 sebesar $27 \mathrm{mg} / \mathrm{L}$ dari ketiga sampel yang belum mengalami filterisasi tersebut nilainya masih dibawah nilai 500 sesuai standar air yang diperbolehkan. Sedangkan untuk sampel yang sudah mengalami filterisasi, untuk sampel B1 memiliki nilai $74 \mathrm{mg} / \mathrm{L}$, sampel B2 memiliki nilai $25 \mathrm{mg} / \mathrm{L}$, dan sampel B3 memiliki nilai sebesar $22 \mathrm{mg} / \mathrm{L}$. Dari kedua sampel diatas nilai dari TDS masih berada dibawah maksimum batas standar air yang diperbolehkan.

3. Nitrat-nitrogen

Nitrogen nitrat yang terdapat dalam air alami hampir tidak pernah melebihi $0.1 \mathrm{mg} / \mathrm{L}$. Hasil pengukuran kadar nitrat pada sampel A dan B pada kisaran 0,041-0,176 cukup baik, karena masih dalam kisaran alami $0,1 \mathrm{mg} / \mathrm{L}$ dan berada di bawah batas maksimum baku air yaitu $50 \mathrm{mg} / \mathrm{L}$. Kadar nitrat mengalami peningkatan dari sebelum disaring dan sesudah disaring.

4. Kesadahan $\left(\mathrm{CaCO}_{3}\right)$

Kekerasan $(\mathrm{CaCO} 3)$ disebabkan oleh adanya dua ion logam valensi (kation) yang dapat bereaksi dengan sabun membentuk kerak. Kekerasan total mengacu pada kekerasan yang disebabkan oleh adanya ion $\mathrm{Ca} 2+$ dan $\mathrm{Mg} 2+$ secara simultan (Siska Musiam, dkk. 2015). Kadar kesadahan maksimum yang diperbolehkan dalam air minum sesuai Peraturan Menteri Kesehatan Republik Indonesia No. 492/MENKES/PER/IV/2010 adalah $500 \mathrm{mg} / \mathrm{L}$. Pada sampel air yang telah diambil, yaitu sampel A1, A2, A3, B1, B2, dan B3 memiliki nilai kesadahan yang sama, yaitu $0 \mathrm{mg} / \mathrm{L}$ artinya kadar kesadahan tersebut memenuhi standar paramteter kesadahan untuk persyaratan kualitas air minum yaitu sebesar $<500 \mathrm{mg} / \mathrm{L}$.

5. Besi

Kandungan zat besi pada air tanah terutama pada air sumur sangat umum dijumpai. Umumnya air tanah dengan konsentrasi karbondioksida yang tinggi dapat menyebabkan kondisi anaerobik. Setrika memiliki konsentrasi tinggi yang dapat menodai kain dan peralatan dapur. Kondisi ini menyebabkan konsentrasi besi dalam bentuk mineral tidak larut $(\mathrm{Fe} 3+)$ menurun menjadi konsentrasi besi terlarut dalam bentuk ion divalen ( $\mathrm{Fe} \mathrm{2+}$ ). Konsentrasi zat besi dalam air tanah berkisar antara $0.01 \mathrm{mg} / \mathrm{L}$ sampai $25 \mathrm{mg} / \mathrm{L}$ (Wiyata, 2003). Pada air permukaan, kandungan zat besi lebih dari $1 \mathrm{mg} / \mathrm{L}$ jarang ditemukan, namun pada air tanah kandungan zat besi lebih tinggi (Manahan, 1999).

WHO menetapkan kadar konsentrasi Fe yang dianjurkan minimal adalah $1 \mathrm{mg} / \mathrm{L}$. berdasarkan sampel pengamatan, yaitu sampel A1, A2, dan A3 memiliki rata-rata nilai kandungan yang lebih rendah dibandingkan dengan sampel B1, B2, dan B3. Dapat disimpulkan bahwa nilai kandungan besi pada sampel $<0.3 \mathrm{mg} / \mathrm{L}$ artinya air tersebut memenuhi standar kualitas air yang berlaku.

6. Mangan

Untuk nilai Mangan sesuai standar kualitas air minum harus berada dibawah nilai $0,4 \mathrm{mg} / \mathrm{L}$. Pada sampel A1 memiliki nilai $0.143 \mathrm{mg} / \mathrm{L}$, sampel A2 memiliki nilai $0,190 \mathrm{mg} / \mathrm{L}$, dan sampel A3 memiliki nilai 0,095 mg/L. Dari ketiga sampel ini masih memiliki nilai $<0,4 \mathrm{mg} / \mathrm{L}$. Sedangkan untuk sampel B1 memiliki nilai sebesar 0,238 mg/L, sampel B2 memiliki nilai $0,048 \mathrm{mg} / \mathrm{L}$, dan sampel B3 memiliki nilai 0,048, dari ketiga sampel ini juga memiliki nilai $<0,4 \mathrm{mg} / \mathrm{L}$. Sampel kelompok A memiliki nilai Mangan yang lebih rendah dibandingkan dengan sampel kelompok B dan sudah memasuki standar yang berlaku yaitu maksimal $0,4 \mathrm{mg} / \mathrm{L}$

7. Detergent

Koefisien deterjen pada sampel A1 memiliki nilai sebesar $1.944 \mathrm{mg} / \mathrm{L}$, sampel A2 bernilai 1,778 $\mathrm{mg} / \mathrm{L}$, dan sampel A3 bernilai 1,333 mg/L. Ketiga sampel ini merupakan sampel yang belum mengalami penjernihan melalui pipa filter. Sedangkan untuk sampel B1 memiliki nilai kadar detergen sebesar 3,611 mg/L, sampel B2 memiliki kadar detergen sebesar 1,389 mg/L, dan sampel B3 memiliki kadar detergen sebesar 1,278 mg/L. sampel B1, B2, dan B3 ini merupakan sampel yang sudah mengalami proses filterisasi melalu pipa filter yang didalamnya terdapat beberapa komponen untuk melakukan penjernihan air. Nilai batas maksimum untuk satandar kualitas air 
minum untuk detergen yaitu $0 \mathrm{mg} / \mathrm{L}$ yang artinya air tersebut harus terbebas dari campuran detergen, namun dari sampel diatas masih memiliki nilai $>0 \mathrm{mg} / \mathrm{L}$, untuk itu perlu dilakukan peninjauan kembali pada pipa filter.

Adanya zeolite dan pasir ini dapat menurunkan kadar deterjen sesuai dengan standar kualitas air minum. Mengurangi kandungan deterjen dapat dicapai dengan koagulasi dan filtrasi dalam media pasir dan zeolit. Untuk mendapatkan efek yang maksimal, perlu untuk mengendap dalam jangka waktu yang lebih lama, dan model filtrasi yang berbeda serta bahan koagulasi yang berbeda harus digunakan. Misalnya biji kelor digunakan sebagai bahan pembekuan alami. (Haderiah dan Novi Utami Dewi, 2016).

Dari hasil analisa laboratoriun utuk sistem penjernihan air ini didapatkan rata-rata untuk sampel A dan B yang dapat dilihat pada Tabel 2.

Tabel 2. Rata-rata perbandingan parameter sampel A dan sampel B

\begin{tabular}{clccccc}
\hline No & Parameter & Satuan & Sampel A & Sampel B & $\begin{array}{c}\text { Standart } \\
\text { Air }\end{array}$ & Keterangan \\
\hline 1 & TSS & $\mathrm{mg} / \mathrm{L}$ & 10.3333 & 0.0000 & - & Memenuhi \\
\hline 2 & TDS & $\mathrm{mg} / \mathrm{L}$ & 33.3333 & 40.3333 & 500 & Memenuhi \\
\hline 3 & Ph & & 6.8000 & 6.7133 & $6.5-8.5$ & Memenuhi \\
\hline 4 & Nitrat & $\mathrm{mg} / \mathrm{L}$ & 0.0857 & 0.1126 & 50 & Memenuhi \\
\hline 5 & Nitrit & $\mathrm{mg} / \mathrm{L}$ & 0.0093 & 0.0080 & 3 & Memenuhi \\
\hline 6 & Sulfat & $\mathrm{mg} / \mathrm{L}$ & 1.9193 & 1.6160 & 250 & Memenuhi \\
\hline 7 & Kesadahan & $\mathrm{mg} / \mathrm{L}$ & 0 & 0 & 500 & Memenuhi \\
\hline 8 & Besi & $\mathrm{mg} / \mathrm{L}$ & 0.0243 & 0.0320 & 0.3 & Memenuhi \\
\hline 9 & Mangan & $\mathrm{mg} / \mathrm{L}$ & 0.1427 & 0.1113 & 0.4 & Memenuhi \\
\hline 10 & Kadmium & $\mathrm{mg} / \mathrm{L}$ & 0 & 0 & 0.003 & Memenuhi \\
\hline 11 & Seng & $\mathrm{mg} / \mathrm{L}$ & 0.3067 & 0.1250 & 3 & Memenuhi \\
\hline 12 & Timbal & $\mathrm{mg} / \mathrm{L}$ & 0 & 0 & 0.01 & Memenuhi \\
\hline 13 & Kromium & $\mathrm{mg} / \mathrm{L}$ & 0.0003 & 0.0013 & 0.05 & Memenuhi \\
\hline 14 & Raksa & $\mathrm{mg} / \mathrm{L}$ & 0 & 0 & 0.001 & Memenuhi \\
\hline 15 & Detergent & $\mathrm{mg} / \mathrm{L}$ & 1.6840 & 2.0927 & 0.05 & Tidak \\
& & & & & & Memenuhi \\
\hline
\end{tabular}

** Standart kualitas air berdasarkan Peraturan Menteri Kesehatan Republik Indonesia No. 492/MENKES/PER/IV/2010 tentang Persyaratan Kualitas Air Minum

Kondisi kualitas air pada sistem penjernihan air hujan ini dengan melihat hasil analisa teranalisis kondisinya semua memenuhi kecuali parameter deterjent. Hal ini akan menjadi bahan untuk penelitian selanjutnya mengenai kondisi parameter deterjent yang terdeteksi di sistem Rain harvesting skala rumah tangga. 
Lufira, Zuhriyah, Muktiningsih, Rahayu, Fauzi : Model Penjernih Air Hujan Untuk Air Bersih

\section{Perbandingan Rata-Rata Parameter Kimia Sampel A dan Sampel B}

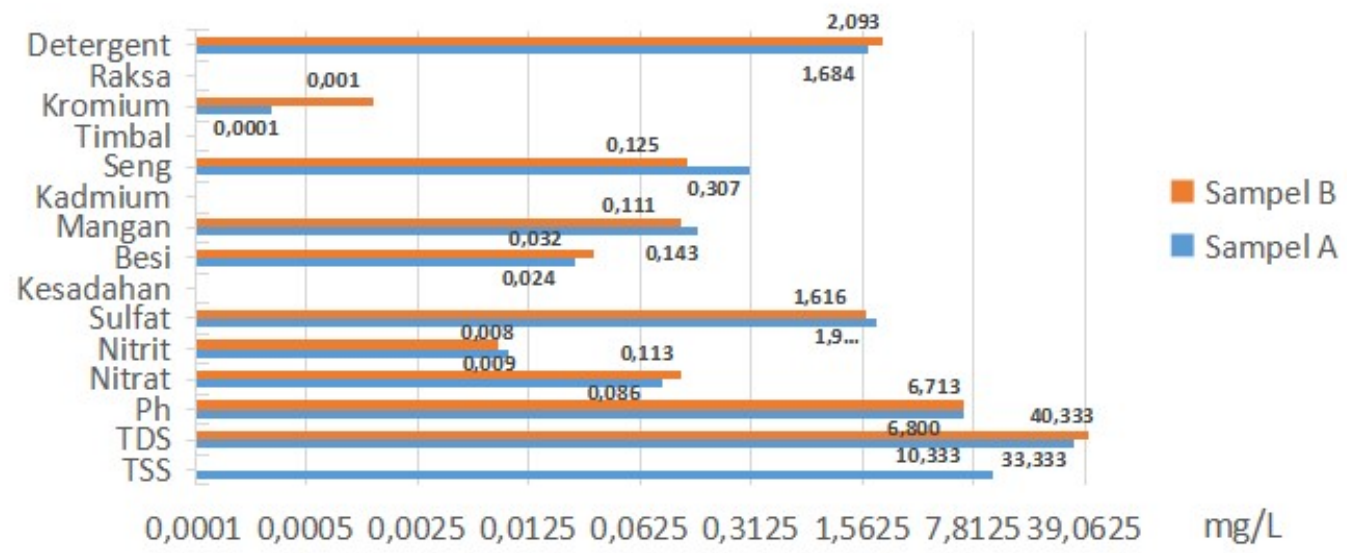

Gambar 4. Grafik perbandingan hasil analisa Kualitas Air Sampel A dan B

Gambar 4 menunjukan kondisi perbandingan yang akan diperlukan penelitian lebih lanjut untuk menganalisa dari sisi parameter biologi dan juga pengujian ulang untuk analisa kondisi parameter kimia teruji. Salah satu metode pengujian parameter biologi adalah metode fotodinamik dgn LED dan induksi medan magnet, dpt mereduksi persentase koloni bakteri pencemar air (E-coli) smp 80\%. Tetapi waktu yg di butuhkan hampir 2 tahun pengujian dan bertahap hasilnya. (Wibowo, 2014).

\section{Kesimpulan}

Dari hasil analisa yang dilakukan di laboratorium diatas dapat diketahui kualitas air sebelum disaring dan sesudah disaring, hasil tersebut dapat dijadikan acuan untuk menentukan apakah sistem penyaringan air bersih tersebut memenuhi kriteria atau tidak. Dimana ada beberapa parameter yang mengalami kenaikan kadar parameternya, hal itu kemungkinan bisa disebabkan salah satunya melalui pipa filter yang digunakan dalam studi ini. Untuk lebih lanjut dapat dilakukan peninjauan secara teknis untuk menganalisa lebih lanjut kondisi tersebut. Namun secara garis besar pengujian yang telat dilakukan tersebut, mendapatkan hasil yang sesuai dengan persyaratan sesuai dengan lapiran dari Peraturan Menteri Kesehatan Republik Indonesia No. 492/MENKES/PER/IV/2010. Sehingga Air yang dipakai memenuhi syarat penggunaan air bersih bukan untuk air minum. Selain itu, secara estetika air hujan tidak layak untuk dikonsumsi karena berdasarkan kenampakkan air hujan berwarna kuning dan sedikit berlumut. Dan perlu adanya kajian lanjutan untuk menganalisis deterjen yang terdeteksi dan juga pengujian ulang lanjutan. Untuk mengetahui penyebab kontaminasi, baik dari pengambilan sampel air ataupun di sistem penyaringan air bersih.

\section{Daftar Pustaka}

Asmaningrum, H. P., \& Pasaribu, Y. P. 2016. Penentuan Kadar Besi (Fe) dan Kesadahan pada Air Minum Isi Ulang di Distrik Merauke. Magistra, 3(2), 95-104.

Dachriyanus,. 2004. Analisis Struktur Senyawa Organik Secara Spektroskopi. Padang, Sumatera Barat, Indonesia. Lembaga Pengembangan Teknologi Informasi dan Komunikasi (LPTIK) Universitas Andalas.

Erna, H., dkk. 2017. Deseminasi: Pembuatan Air Bersih Dengan Memanfaatkan Air Hujan Melalui Penyaring Pipa Bersusun Berbasis Adsorben Alami. Prosiding Seminar Nasional Publikasi Hasil-Hasil Penelitian dan Pengabdian Masyarakat. Universitas Muhammadiyah Semarang.

Gupta, H. and Roy, S. 2007. Geothermal Energy an Alternate Resource for the 21 st Century. Amsterdam: Elsevier B.V. 
Haderiah \& Novi Utami Dewi. 2016. Meminimalisir Kadar Detergen dengan Penambahan Koagulan dan Filtrasi Media Saring pada Limbah Kamar Mandi. Higiene, 1(1), 33-41.

Menteri Kesehatan Republik Indonesia. 2017. Peraturan Menteri Kesehatan Republik Indonesia Nomor 32 Tahun 2017 Tentang Standar Baku Mutu Kesehatan Lingkungan Dan Persyaratan Kesehatan Air Untuk Keperluan Higiene Sanitasi, Kolam Renang, Solus Per Aqua dan Pemandian Umum. Peraturan Menteri Kesehatan Republik Indonesia, 1-20.

Manahan S.E. 1999. Environmental Chemistry, Seventh Edition. New York: Lewis Publishers.

Musiam, S., Darmiani, S., \& Putra, A. M. P. 2017. Analisis Kuantitatif Kesadahan Total Air Minum Isi Ulang Yang Dijual Di Wilayah Kayu Tangi Kota Banjarmasin. Jurnal Ilmiah Manuntung, $1(2), 145-148$.

Sahetapy, J. M. F. 2018. Pengaruh Perbedaan Konsentrasi Deterjen Bubuk terhadap Frekuensi Bukaan Operkulum dan Kelangsungan Hidup Ikan Mas (Cyprinus carpio) (The Effect of Different Surfactant to Frequency of Openings Operculum and Survival Rate of Grass Carp Cyprinus carpio. 14(April), 35-40.

Untari, T., \& Kusnadi, J. 2015. Pemanfaatan Air Hujan Sebagai Air Layak Konsumsi Di Kota Malang Dengan Metode Modifikasi Filtrasi Sederhana Utilization Rainwater As A Viable Water Consumption In The Malang City With A Simple Filtration Modification Method. 3(4), $1492-1502$.

Wardani, Novianti Tri Kusuma. 2017. "Skripsi Pengaruh Co ( Ii ) Pada Analisis Besi ( Iii ) Dengan Pengompleks 1, 10- Fenantrolin Pada pH 3 , 5 Secara Spektrofotometri Uv-Vis." (Ii): 11.

Wibowo, Arif and Suryani, Dyah Astuti. 2013. Optimasi Fotoinaktivasi Bakteri Pencemar Air (Escherichia Coli) Dengan Induksi Medan Magnet Frekuensi Rendah. Universitas Airlangga, Surabaya. 